National Marine

Fisheries Service

NOAA
Fishery Bulletin

a established in 1881 a
Spencer F. Baird

First U.S. Commissione of Fisheries and founder of Fishery Bulletin

\author{
Abstract-The sheepshead (Archos- \\ argus probatocephalus) is common in \\ coastal waters from the Chesapeake \\ Bay to Texas in the United States \\ and supports a viable recreational \\ and commercial fishery throughout \\ much of its range. Otoliths were ex- \\ tracted from 2549 sheepshead col- \\ lected from 1993 through 2009 in \\ Tampa Bay, Florida, during routine \\ sampling by the Fisheries-Indepen- \\ dent Monitoring program of the Flor- \\ ida Fish and Wildlife Conservation \\ Commission. Sheepshead ranged in \\ size from 107 to $524 \mathrm{~mm}$ fork length \\ (FL). Age of sheepshead was esti- \\ mated by counting annuli (opaque \\ zones) in thin-sectioned sagittal oto- \\ liths. Marginal-increment analysis \\ of sheepshead from ages 1 to 6 indi- \\ cated that a single opaque ring was \\ Brent L. Winner (contact author) ${ }^{1}$ \\ Timothy C. MacDonald ${ }^{1}$ \\ Kimberly B. Amendola ${ }^{2}$ \\ Email address for contact author: brent.winner@myfwc.com \\ 1 Fish and Wildlife Research Institute \\ Florida Fish and Wildlife Conservation Commission \\ 100 Eighth Avenue Southeast \\ St. Petersburg, Florida 33701-5020 \\ 2 Southeast Regional Office \\ National Marine Fisheries Service, NOAA \\ 263 13th Avenue South, Suite 113 \\ St. Petersburg, Florida 33701
} formed on an otolith each year between May and June. In Tampa Bay, sheephead reached a maximum age of 15 years. Males and females experienced rapid growth through age 6 ; growth rate decreased markedly thereafter. Although von Bertalanffy growth models were biologically similar between sexes, they were found to be statistically different (female $\left[F L=419.1\left(1-\mathrm{e}^{-0.272(\text { age }+1.009)}\right)\right]$; males $\left.\left[F L=422.5\left(1-\mathrm{e}^{-0.255(\text { age }+1.115)}\right)\right]\right)$. Tampa Bay sheepshead are typically smaller at a given age than those in more northern climates and not as long lived. Differences in regional growth models may be attributed to differences in mortality, ontogenetic shifts in habitat, genetic variation, or sampling design.

Manuscript submitted 28 April 2016. Manuscript accepted 15 December 2016. Fish. Bull. 115:155-166 (2017).

Online publication date: 31 January 2017. doi: 10.7755/FB.115.2.3

The views and opinions expressed or implied in this article are those of the author (or authors) and do not necessarily reflect the position of the National Marine Fisheries Service, NOAA.
The sheepshead (Archosargus probatocephalus) occurs from Nova Scotia (Gilhen et al., 1976) to Brazil (Caldwell, 1965) and is common in coastal waters from Chesapeake Bay to Texas in the United States (Bigelow and Schroeder, 1953; Collette and Klein-MacPhee, 2002). Two subspecies of sheepshead have been reported within its U.S. range: $A$. p. probatocephalus, found along the Atlantic coast and into the Gulf of Mexico as far north as Steinhatchee, Florida, and A. p. oviceps, which occurs in the Gulf of Mexico from St. Marks River, Florida, to Campeche Bank, Mexico (Caldwell, 1965). Subspecific distinction is based partly on pigmentation (size and number of vertical body bars) and meristic counts (lateral line scales, gill rakers, and dorsal fin spines and rays), both of which overlap considerably between the 2 subspecies (Caldwell, 1965). Results of recent genetic analyses in which mtDNA of sheepshead from the Gulf of Mexico and South Atlantic indicated that a single panmictic population of sheepshead exists within the range of this species from Texas through North Carolina

\title{
Age and growth of sheepshead (Archosargus probatocephalus) in Tampa Bay, Florida
}

(Anderson et al., 2008; Seyoum et al., in press). More detailed microsatellite analysis, however, has revealed a significant genetic break at the subspecies boundary in the Florida panhandle (Apalachee Bay), providing genetic support for the validity of 2 subspecies of sheepshead within its range in the United States (Seyoum et al., in press).

The combined recreational and commercial landings of sheepshead from the gulf coast of Florida between 1990 and 2009 made up 19$44 \%$ of the total annual landings of sheepshead for all U.S. states in the Gulf of Mexico (National Marine Fisheries Service, Fisheries Statistics and Economics Division commercial annual landings statistics, available from website, accessed June 2014, and Marine Recreational Information Program time-series data, available from website). The combined annual landings from the gulf coast of Florida peaked at 1755.6 metric tons in 1992; from 1996 to 2009, they averaged less than half that amount (841.3 metric tons/year) because of enactment in 1995 of a Florida constitutional amendment that limits 
the use of entangling nets and mandates the institution of minimum size and bag limits for recreational fishermen (Munyandorero et al. ${ }^{1}$ ). Historically, more sheepshead have been landed by recreational fishermen than commercial fishermen (70-95\% of the combined annual landings during 1990-2009) along Florida's gulf coast (Munyandorero et al. ${ }^{1}$ ).

Growth has been described for larval and early juvenile sheepshead from Florida waters (Parsons and Peters, 1989). Elsewhere, age and growth studies of juvenile and adult sheepshead have been conducted in Georgia (Music and Pafford ${ }^{2}$ ), North Carolina (Schwartz, 1990), South Carolina (Wenner ${ }^{3}$ ), Louisiana (Beckman et al., 1991), and northwest Florida (DutkaGianelli and Murie, 2001). Validated (Music and Pafford $^{2}$ ) and unvalidated (Schwartz, 1990) ages have been determined also from scales. However, Dutka-Gianelli and Murie (2001) reported that scales of sheepshead older than 3 years resulted in underestimated ages, and scales from sheepshead aged 2 or more years have been described as unreadable (Schwartz, 1990; Wenner ${ }^{3}$ ).

Validated ages determined from otolith sections have been used to estimate von Bertalanffy growth parameters for sheepshead from Louisiana (Beckman et al., 1991), South Carolina (Wenner ${ }^{3}$ ), and northwest Florida (Dutka-Gianelli and Murie, 2001). All 3 studies noted a high variability in size at age for sheepshead, reported von Bertalanffy growth parameters, and the predicted sizes at age varied considerably among the 3 studies (Dutka-Gianelli and Murie, 2001). Each study relied almost exclusively on the fishery (commercial or recreational) for its samples. Beckman et al. (1991) indicated that because the gear types used were more apt to catch certain sizes of fish than others and because fishermen occasionally sorted the catch before supplying the researchers with samples, the age and size structures of the sheepshead analyzed probably did not represent the overall population of sheepshead in Louisiana. Other researchers also have determined that reliance upon samples obtained only from the fishery can cause misrepresentation of the size distribution and age structure of a population (Miranda et al., 1987; Hilborn and Walters, 1992; Wilson et al., 2015).

By design, we used multiple gear types and fisheries-independent methods to provide a more representative sample across size and age classes of sheepshead, therefore generating estimates of growth pa-

\footnotetext{
${ }^{1}$ Munyandorero, J., J. O'Hop, and C. Guenther. 2011. An assessment of the status of sheepshead in Florida waters through 2009. Florida Fish Wildl. Conserv. Comm., Fish Wildl. Res. Inst., IHR 2011-003, 137 p. Fish and Wildlife Research Institute, St. Petersburg, FL. [Available from website.]

2 Music, J. L., Jr., and J. M. Pafford. 1984. Population dynamics and life history aspects of major marine sportfishes in Georgia's coastal waters, 382 p. Coast Res. Div., Georgia Dep. Nat. Resour., Atlanta GA.

${ }^{3}$ Wenner, C. 1996. Age and growth of sheepshead, Archosargus probatocephalus, from South Carolina waters with some preliminary management concepts, 17 p. S. Carolina Dep. Nat. Resour., Charleston, SC.
}

rameters more representative of the true population. Otolith annuli (opaque zones) were validated to determine age and growth parameters for sheepshead, and these estimates were then compared with those previously reported for sheepshead from other geographical regions.

\section{Materials and methods}

Sheepshead were collected in Tampa Bay, Florida (Fig. 1), a large estuary on the west coast of Florida that has an average depth of approximately $3 \mathrm{~m}$ and a maximum depth of $13 \mathrm{~m}$ (Comp and Seaman, 1985). All sheepshead were captured from 1993 through 2009 by the Fish and Wildlife Research Institute's Fisheries-Independent Monitoring program during routine sampling with haul seines, trawls, gill nets, and trammel nets (Table 1). Haul seine and trawl samples were collected at both stratified-random and fixed sites; gill net collections were made at stratified-random sites. More detailed information about the sampling gears and protocols used by the Fisheries-Independent Monitoring program can be found in Tremain and Adams (1995), Nelson et al. (1997), Nelson (1998), and Winner et al. (2010). Sheepshead were also taken as bycatch from trammel nets, which had been set on visually detected schools of striped mullet (Mugil cephalus), red drum (Sciaenops ocellatus), or common snook (Centropomus undecimalis). For each fish, we recorded standard length (SL), fork length (FL), and total length (TL) to the nearest millimeter; sex; and total weight to the nearest $0.1 \mathrm{~g}$ before extraction of sagittal otoliths, which were then rinsed, cleaned, and stored dry for further examination.

Sex ratios of sheepshead were compared with a hypothetical 1:1 sex ratio by using the $G$-test (Sokal and Rohlf, 1981). Length distributions also were compared between sexes by using the Kolmogorov-Smirnov (KS) 2 -sample test (Proc Npar1way procedure in $\mathrm{SAS}^{4}$ software, vers. 5.1 (SAS Institute Inc., Cary, NC). Linear regression for all sheepshead collected was used to calculate sex-specific length-length and length-weight relationships (Proc Reg procedure in SAS software) for untransformed and transformed $\left(\log _{10}\right)$ data, respectively, and these relationships were compared through analysis of covariance (ANCOVA; Snedecor and Cochran, 1967). Data from all fish collected were pooled when slopes and intercepts for sex-specific regressions were not significantly different. All significance testing was conducted at $P \leq 0.05$.

Three or four thin $(\sim 0.5 \mathrm{~mm})$ transverse sections were cut at or adjacent to the core of the left sagitta with a Buhler Isomet low-speed saw equipped with a diamond blade; a right sagitta was sectioned when the left sagitta was missing or had been damaged. Oto-

\footnotetext{
${ }^{4}$ Mention of trade names or commercial companies is for identification purposes only and does not imply endorsement by the National Marine Fisheries Service, NOAA.
} 


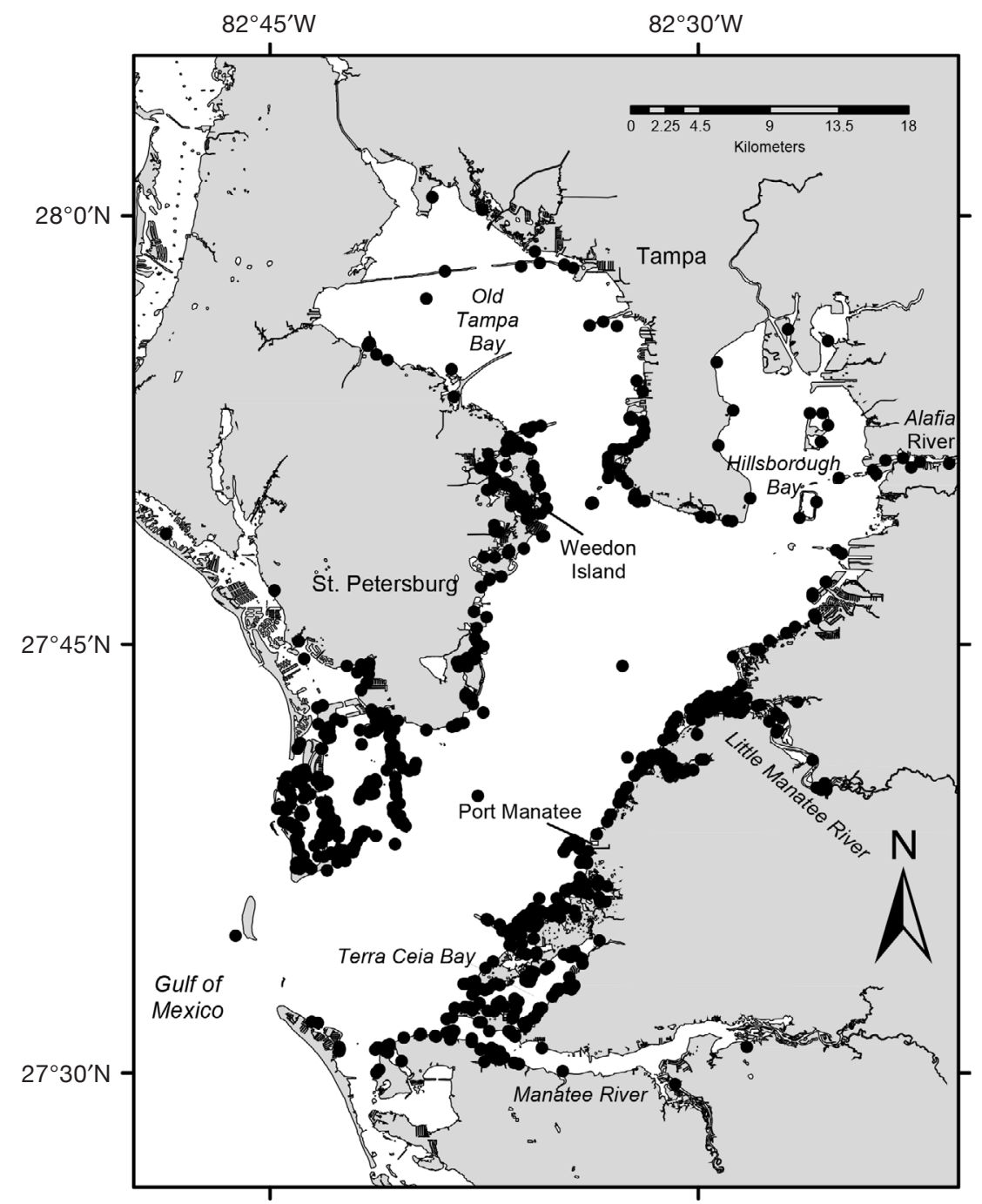

Figure 1

Sampling locations (indicated by black circles) in Tampa Bay, Florida, where sheepshead (Archosargus probatocephalus) were collected during 1993-2009 for age and growth analysis under the guidance of the Fisheries-Independent Monitoring program of the Florida Fish and Wildlife Conservation Commission. the proximal edge of each annulus, along the ventral sulcal ridge, were completed with a digital imageprocessing system for all otoliths processed from 1995 through 1998. The marginal increment was calculated as a percentage by dividing the distance from the terminal annulus to the marginal edge by the distance between the last 2 annuli formed on the otolith and multiplying by 100 . Monthly marginal-increment statistics (25th, 50th, and 75th percentiles) with all age classes pooled were calculated for February 1995-December 1998, the period during which monthly samples were collected consistently. Additionally, monthly marginal-increment statistics were plotted, with months pooled across all years (1995-1998), for individual age classes (ages 1-6 only). Fish age 7 and older were excluded from these age-class-specific analyses because of low sample size across sampled months.

Age of each sheepshead was calculated on the basis of annulus count, marginal increment, date of capture, and an assumed hatching date of 1 April (an assumption based on spawning and larval recruitment; Parsons and Peters, 1989; Tucker and Alshuth, 1997). Therefore, sheepshead collected in February and March that had recently formed an annulus, as determined by a low $(<30 \%)$ marginal increment were assigned an age of one less than the ring count. Fish collected in April, May, or June that were about to deposit an annulus (at $>80 \%$ marginal increment) were assigned an age of one more than the ring count. All

lith sections were mounted on microscope slides by using Histomount solution (Thermo Fisher Scientific, Waltham, MA). With a dissecting microscope (8-25x magnification), 2 or 3 readers independently counted the opaque rings on each otolith twice under reflected light. Readers counted rings without knowing the sex, length, or capture date of specimens. Disagreements in annulus counts were resolved by at least 2 readers, without knowledge of previous counts. If an annulus count could not be agreed upon after reexamination, the otolith was rejected from the age and growth analysis.

Validation of annuli counts was completed through marginal-increment analysis, which provided indirect evidence at the otolith margin of the periodicity of annulus formation. Measurements from the core to other fish were assigned an age equal to the ring count. Daily age was calculated on the basis of the age and the number of days that had passed between 1 April and the date of collection:

$$
\text { (integer age + number of days)/365. }
$$

The $G$-test was used to compare sex ratios for all fish collected and subsets of fish kept for or eliminated from the aging analysis. Lengths of retained and eliminated sheepshead were compared by using the KS 2-sample test (Proc Npar1way procedure; SAS, 2006). The KS test was also used to compare age-frequency distributions between the sexes.

The von Bertalanffy (1957) growth equation,

$$
L_{\mathrm{t}}=L_{\infty}\left(1-e^{-k\left(t-t_{0}\right)}\right),
$$




\section{Table 1}

Descriptive statistics for fork length and age (mean, minimum, maximum, and standard deviation [SD]) and total catch of sheepshead (Archosargus probatocephalus) collected in Tampa Bay, Florida, in 1993-2009, by gear type.

\begin{tabular}{|c|c|c|c|c|c|c|c|c|c|}
\hline \multirow[b]{2}{*}{ Gear type } & \multirow[b]{2}{*}{ Number of fish } & \multicolumn{4}{|c|}{ Fork length (mm) } & \multicolumn{4}{|c|}{ Age (years) } \\
\hline & & Mean & Min & Max & $\mathrm{SD}$ & Mean & Min & Max & $\mathrm{SD}$ \\
\hline Small haul seines & 52 & 287.0 & 153 & 415 & 65.2 & 3.5 & 0.9 & 6.9 & 1.6 \\
\hline Large haul seines & 1931 & 299.4 & 107 & 524 & 63.7 & 4.1 & 0.5 & 15.2 & 2.1 \\
\hline Purse seines & 50 & 256.1 & 173 & 465 & 62.3 & 3.1 & 1.2 & 7.9 & 1.6 \\
\hline Gill nets & 62 & 284.2 & 158 & 409 & 59.3 & 3.7 & 1.0 & 9.6 & 2.0 \\
\hline Otter trawls & 36 & 254.6 & 159 & 383 & 55.7 & 3.4 & 1.3 & 11.6 & 2.3 \\
\hline Trammel nets & 367 & 322.9 & 146 & 458 & 48.3 & 4.5 & 0.6 & 11.5 & 1.8 \\
\hline Unknown & 51 & 318.2 & 190 & 433 & 52.8 & 4.8 & 1.3 & 10.5 & 1.7 \\
\hline Total catch & 2549 & & & & & & & & \\
\hline
\end{tabular}

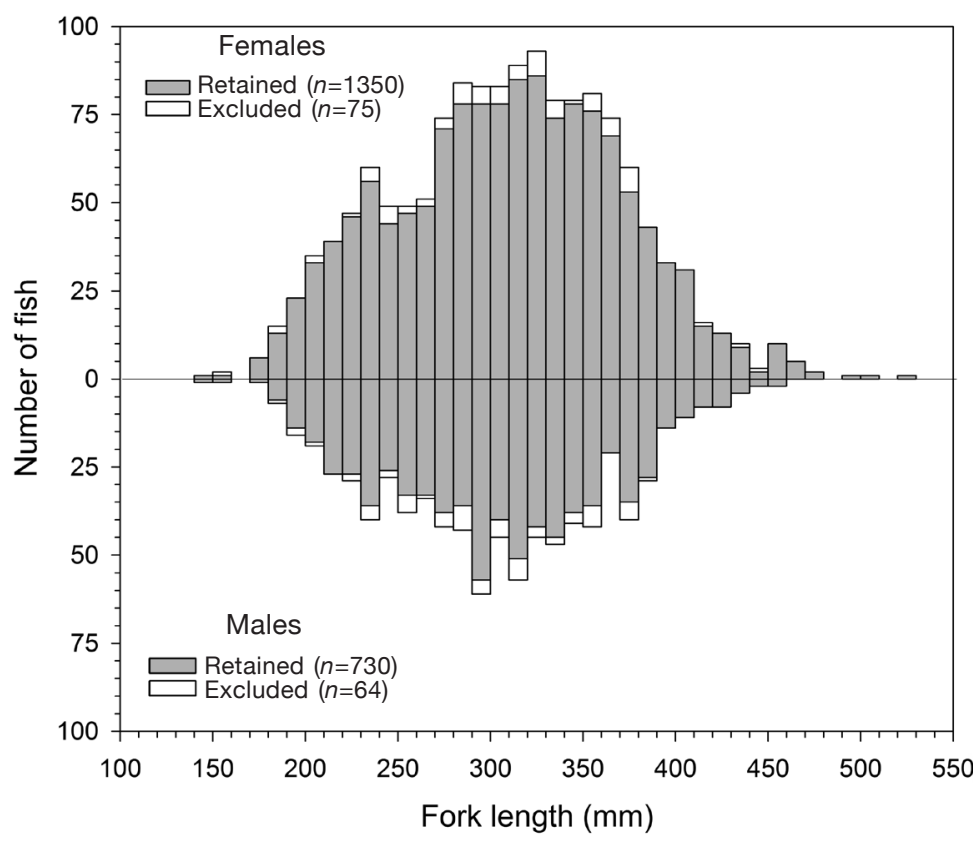

Figure 2

Length-frequency distributions for female and male sheepshead ( $A r$ chosargus probatocephalus) collected in Tampa Bay, Florida, 19932009. Sheepshead that were retained and excluded (otolith identified as unreadable) from the age and growth analysis are depicted. Sheepshead for which there was both age and sex information but which did not have a measured fork length were excluded from this plot

Growth models for males and females were compared with an approximate randomization test (Helser, 1996).

\section{Results}

\section{Size and sex composition}

Sheepshead $(n=2549)$ ranging in size from 107 to $524 \mathrm{~mm}$ FL were collected in Tampa Bay (Fig. 1) with a variety of gear types (Table 1). Although sampling was done throughout the estuary, most specimens were collected along the shoreline in the middle to lower portions of the estuary with a large haul seine $(n=1931$, $75.8 \%)$ or a trammel net $(n=367,14.4 \%)$. Together, the other gear types caught less than $10 \%$ of the specimens used in this study.

Sex was determined for $93 \%$ of the sheepshead collected. The majority of the specimens for which sex was not determined were immature ( $\leq 2$ years old) fish for which gonad samples were too small to allow sex determination. The sex ratio of males to females $(1: 1.75)$ in our samples was significantly different from 1:1 ( $G$-test: 177.69, $\mathrm{df}=1, P \leq 0.001)$. Mean length of females (308.5 mm FL) was slightly greater than that of males (302.0 mm FL), but length-frequency dis-

where $\mathrm{L}_{\mathrm{t}}=$ the observed FL at time $t$;

$L_{\infty}=$ the asymptotic FL;

$k=$ the growth coefficient;

$t=$ the observed age; and

$t_{0}=$ the hypothetical age at size zero, was fit by nonlinear regression (Proc NLin procedure, Marquardt routine in SAS software) for sex-specific observed age and length data. tributions did not differ significantly between sexes (Fig. 2; KS test: 0.058, $P \geq 0.05$ ). Neither the slopes nor the intercepts differed significantly in the sex-specific length-length regressions (ANCOVA: $P>0.05$ ); therefore, all sheepshead data were pooled to elucidate relationships among SL, FL, and TL (Table 2). All length-length regressions exhibited high coefficients of determination $\left(r^{2} \geq 0.988\right)$ (Table 2$)$. Sex-specific length- 


\begin{tabular}{|c|c|c|c|c|c|}
\hline \multicolumn{6}{|c|}{ Table 2} \\
\hline \multicolumn{6}{|c|}{$\begin{array}{l}\text { Length-length and length-weight regressions for sheepshead (Archosargus pro- } \\
\text { batocephalus) collected in Tampa Bay, Florida, 1993-2009. Measurements include } \\
\text { standard length (SL) in millimeters, fork length (FL) in millimeters, total length } \\
\text { (TL) in millimeters, and total weight (WT) in grams. Values in parentheses are } \\
\text { standard errors. Sex-specific length-weight regressions were necessary because } \\
\text { male and female regressions had significantly different intercepts. } r^{2}=\text { coefficient } \\
\text { of determination. }\end{array}$} \\
\hline \multirow[b]{2}{*}{$Y$} & \multirow[b]{2}{*}{$X$} & \multicolumn{4}{|c|}{$Y=a+b X$} \\
\hline & & $n$ & $a$ & $b$ & $r^{2}$ \\
\hline TL & FL & 2218 & $\begin{array}{c}0.853 \\
(0.491)\end{array}$ & $\begin{array}{c}1.094 \\
(0.002)\end{array}$ & 0.995 \\
\hline TL & SL & 2344 & $\begin{array}{l}12.676 \\
(0.742)\end{array}$ & $\begin{array}{c}1.215 \\
(0.003)\end{array}$ & 0.988 \\
\hline FL & $\mathrm{TL}$ & 2218 & $\begin{array}{c}0.621 \\
(0.448)\end{array}$ & $\begin{array}{c}0.910 \\
(0.001)\end{array}$ & 0.995 \\
\hline FL & SL & 2218 & $\begin{array}{c}11.318 \\
(0.629)\end{array}$ & $\begin{array}{c}1.109 \\
(0.002)\end{array}$ & 0.990 \\
\hline $\mathrm{SL}$ & FL & 2218 & $\begin{array}{c}-7.559 \\
(0.582)\end{array}$ & $\begin{array}{c}0.893 \\
(0.002)\end{array}$ & 0.990 \\
\hline $\mathrm{SL}$ & $\mathrm{TL}$ & 2344 & $\begin{array}{c}-7.178 \\
(0.627)\end{array}$ & $\begin{array}{c}0.813 \\
(0.002)\end{array}$ & 0.988 \\
\hline $\log _{10}(\mathrm{WT})$, females & $\log _{10}(\mathrm{FL})$ & 1406 & $\begin{array}{c}-4.508 \\
(0.031)\end{array}$ & $\begin{array}{c}2.960 \\
(0.013)\end{array}$ & 0.976 \\
\hline $\log _{10}(\mathrm{WT})$, males & $\log _{10}(\mathrm{FL})$ & 792 & $\begin{array}{r}-4.367 \\
(0.038)\end{array}$ & $\begin{array}{c}2.899 \\
(0.015)\end{array}$ & 0.978 \\
\hline
\end{tabular}

weight regressions were necessary because regressions for males and females had significantly different intercepts (ANCOVA: $F=32.15 ; \mathrm{df}=1,2196 ; P \leq 0.001$ ), but $r^{2}$ was high for both males $(\geq 0.978)$ and females $(\geq 0.976)$ (Table 2).

\section{Age determination and validation}

Marginal-increment analysis of otoliths from sheepshead, with all age classes pooled, indicated that a single opaque ring formed annually between May and June (Fig. 3). Median marginal increment reached a consistent minimum from late spring to early summer (May 1995, June 1996, June 1997, June 1998) and a consistent maximum during winter (February 1995, January 1996, February 1997, January 1998). Large interquartile ranges in the months before and during opaque-ring deposition indicated that many individuals had either just deposited (and therefore had a low increment width) or were about to deposit an opaque ring (and had a high increment width). Pooling month- ly marginal increments across all years for individual age classes (ages 1-6) also indicated that for each age class a single opaque ring was deposited during the late spring or summer (Fig. 4).

Otoliths of 2549 sheepshead were examined for age; $154(6.0 \%)$ were excluded from the aging analysis (because there was no agreement among readers or because an otolith was damaged), and $169(6.6 \%)$ were excluded from sex-specific age analyses (because no sex data were available). The male to female sex ratio for the sheepshead retained in the aging analysis (1:1.79) did not differ significantly from that of the overall sample $(1: 1.75 ; G$-test: $0.340, \mathrm{df}=1, P>0.05)$. But the male-to-female sex ratio for sheepshead excluded from the aging analysis (1:1.20) was significantly different from that of sheepshead retained in the aging analyses ( $G$-test: $5.06, \mathrm{df}=1, P<0.05)$. Sexspecific length-frequency distributions of fish excluded from the analysis did not differ significantly from those retained (Fig. 2; KS test: females, 0.084, $P>0.05$; males, 0.102, $P>0.05$ ). 


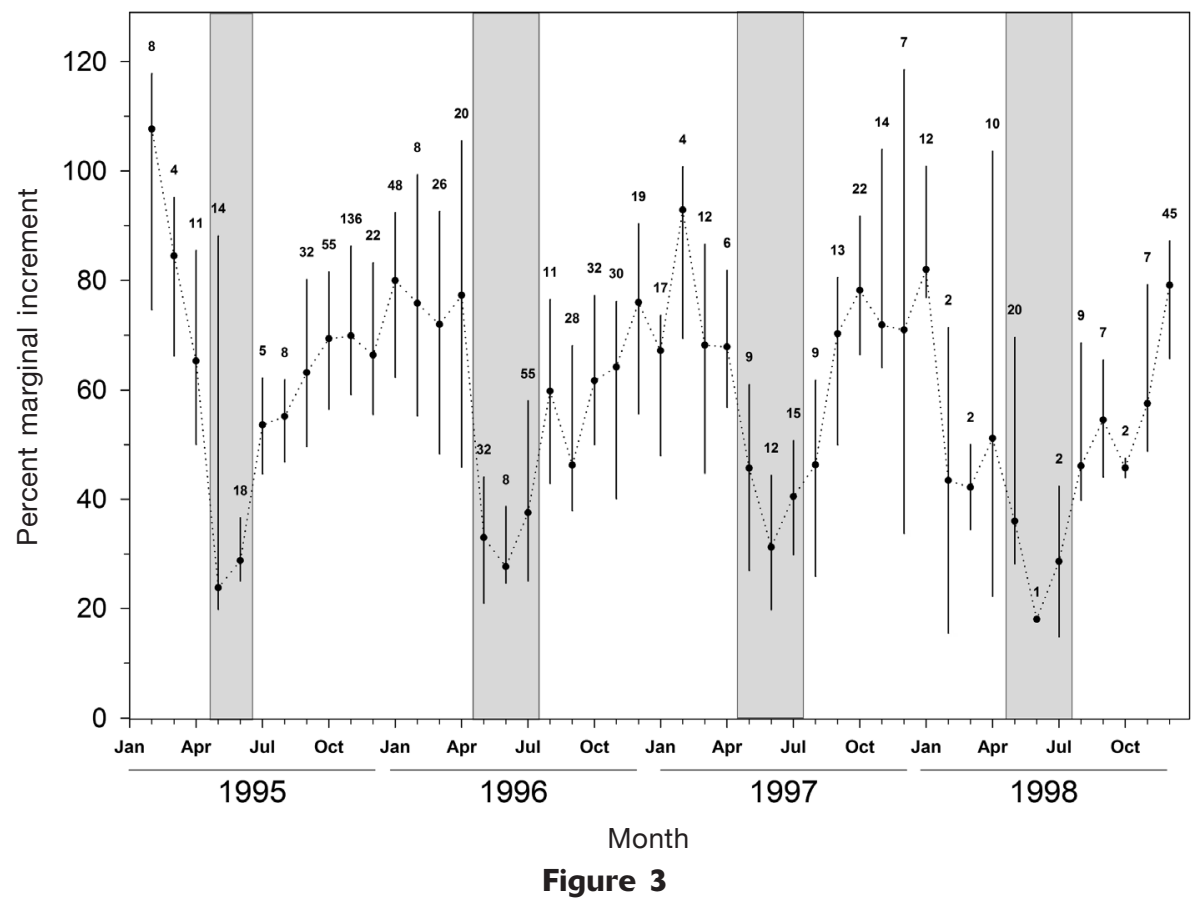

Median monthly percent marginal increment (indicated by black points) for otoliths of sheepshead (Archosargus probatocephalus), all ages combined, collected in Tampa Bay, Florida, 1995-1998. Vertical lines indicate the interquartile ranges. Numbers above monthly percent marginal increments indicate sample sizes. Months of minimal marginal increment (indicating annuli deposition) are highlighted in gray boxes.

\section{Age and growth}

Sheepshead ranged from $<1$ year to 15 years of age, and the mean ages of males (3.67 years) and females (3.73 years) were similar (Fig. 5). The overall age-frequency distributions of males and females (Fig. 5) did not differ significantly (KS test: $0.032, P>0.05$ ). Sheepshead of ages 2-4 accounted for more than half of the individuals collected $(62.9 \%)$, but sheepshead aged 7 or older were relatively rare $(7.9 \%)$. The oldest fish (sex not determined: $524 \mathrm{~mm} \mathrm{FL,} 14.7$ years; male: $404 \mathrm{~mm}$ FL, 14.9 years; and female: $345 \mathrm{~mm}$ FL; 15.2 years) were collected in a large haul seine.

Observed length at age was variable for both sexes (Fig. 6). Growth was relatively rapid for both males and females. By age 1 , sheepshead, regardless of sex, reached a size predicted to be more than $40 \%$ of $L_{\infty}$, and, by age 6 , they had reached sizes greater than $80 \%$ of $L_{\infty}$. Growth rates of both sexes slowed after age 6. Males achieved a slightly greater $L_{\infty}$ than females (3.4 mm FL greater), but females grew at a slightly higher rate (as measured by $K$; Table 3 , Fig. 6) than males. The von Bertalanffy growth models for males and females (approximate randomization test: $P<0.01$ ) were significantly different. Although predicted size at age was greater for females than for males in all age classes from ages 1 through 10 (Table 4), the difference between predicted size at age between sexes was mini- mal, $7 \mathrm{~mm}$ FL or less (mean difference of $3.3 \mathrm{~mm} \mathrm{FL}$ ) across all age classes.

\section{Discussion}

\section{Age determination and validation}

Sheepshead age and growth has been studied by using both scales and sagittal otoliths. Although scales have been used to age sheepshead (Music and Pafford2; Schwartz, 1990; and Wenner ${ }^{3}$ ), validation of annuli on scales of sheepshead has indicated that scales are not as reliable as otoliths for aging this species. Music and Pafford $^{2}$ could validate scale annuli only in sheepshead younger than age 5, and annuli in scales of sheepshead older than age 2 have been reported to be unreadable (Schwartz, 1990; Wenner ${ }^{3}$ ). Age has been underestimated in sheepshead and other fish species when scales were used, and age estimates from the use of scales have been lower than those derived from otolith sections (Beamish and McFarlane, 1983; Carlander, 1987; Lowerre-Barbieri et al., 1994; Dutka-Gianelli, 1999). In our discussion, the only studies considered in growth comparisons are those in which ages were estimated on the basis of validated otolith annuli.

We used marginal-increment analysis, which has been used to validate annulus deposition in the sag- 


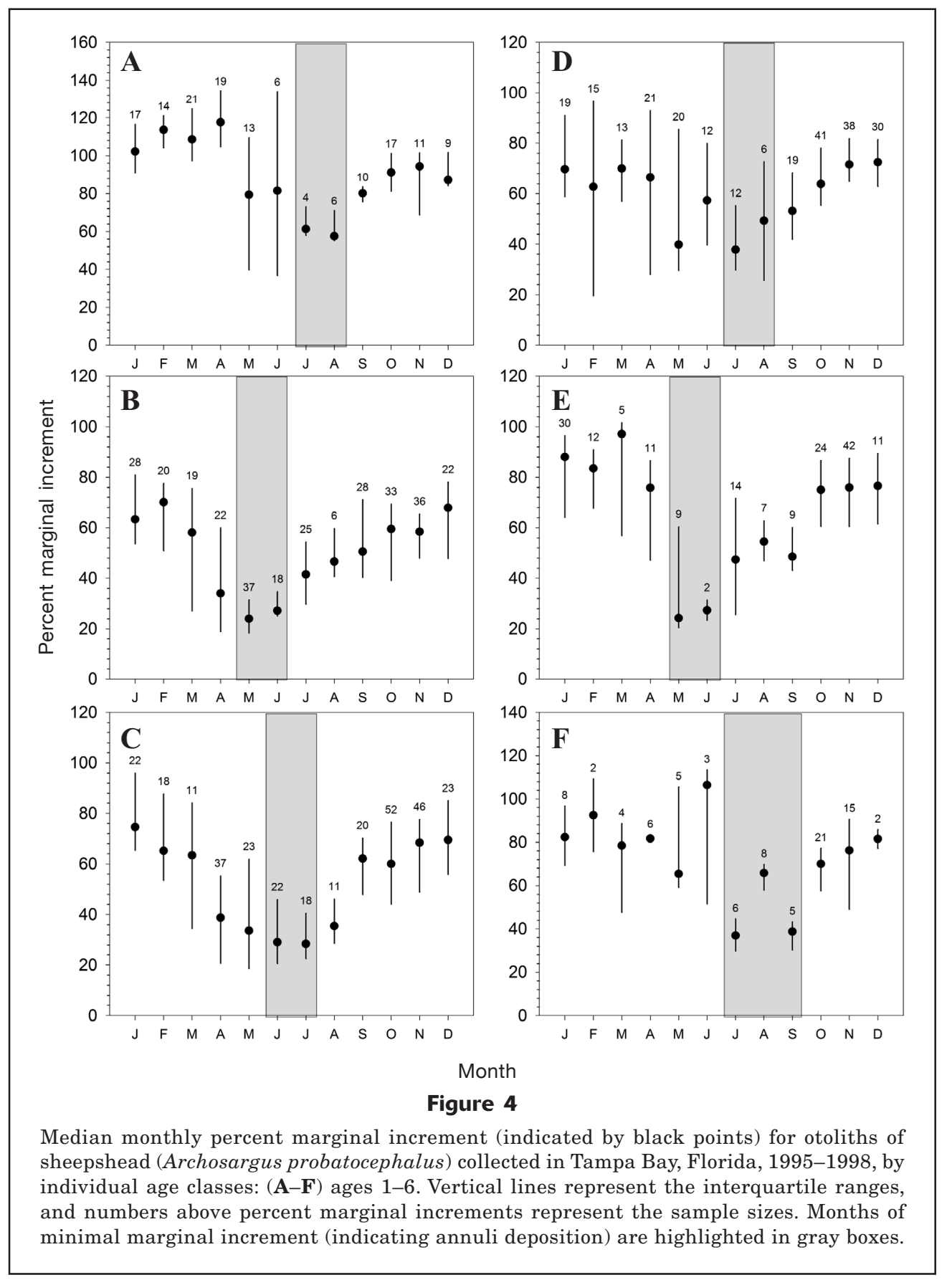

ittae of sheepshead from other areas. Studies from Louisiana (Beckman et al., 1991), northwest Florida (Dutka-Gianelli and Murie, 2001), and South Carolina (individual age classes, <age 5; Wenner ${ }^{3}$ ) used marginal-increment analysis to validate the deposition of a single annulus per year. Chemical marking with oxytetracycline validated the annual deposition of a single opaque ring in sheepshead of ages 2-3 (Dutka-Gianelli and Murie, 2001). Each of these studies reported that a single annulus was deposited from late winter to spring (March-May for sagittae)—a finding similar to that of our study (May-June).
In our study, fish older than age 7 were uncommon; therefore, we could not analyze marginal increments for those fish by age class to validate annulus deposition. Examination of fish aged 7-14, as a group, showed that annuli formed at the same time as fish in younger age classes. Although we presume that these older fish laid down a single opaque ring each year, ages of fish older than age 6 may sometimes have been misinterpreted (Beamish and McFarlane, 1983). It would be valuable in future studies in the Tampa Bay area that more age data be collected from larger and older sheepshead to further elucidate annulus deposition in these older fish. 


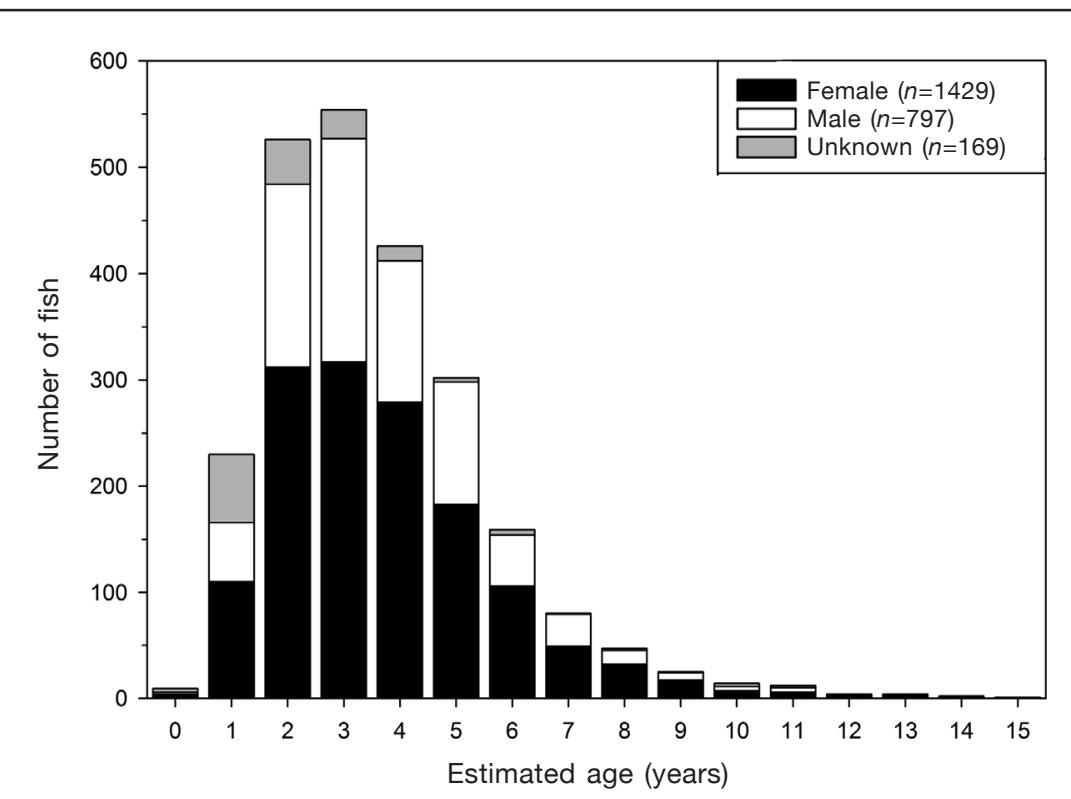

Figure 5

Age-frequency distributions for sheepshead (Archosargus probatocephalus) collected in Tampa Bay, Florida, 1993-2009.

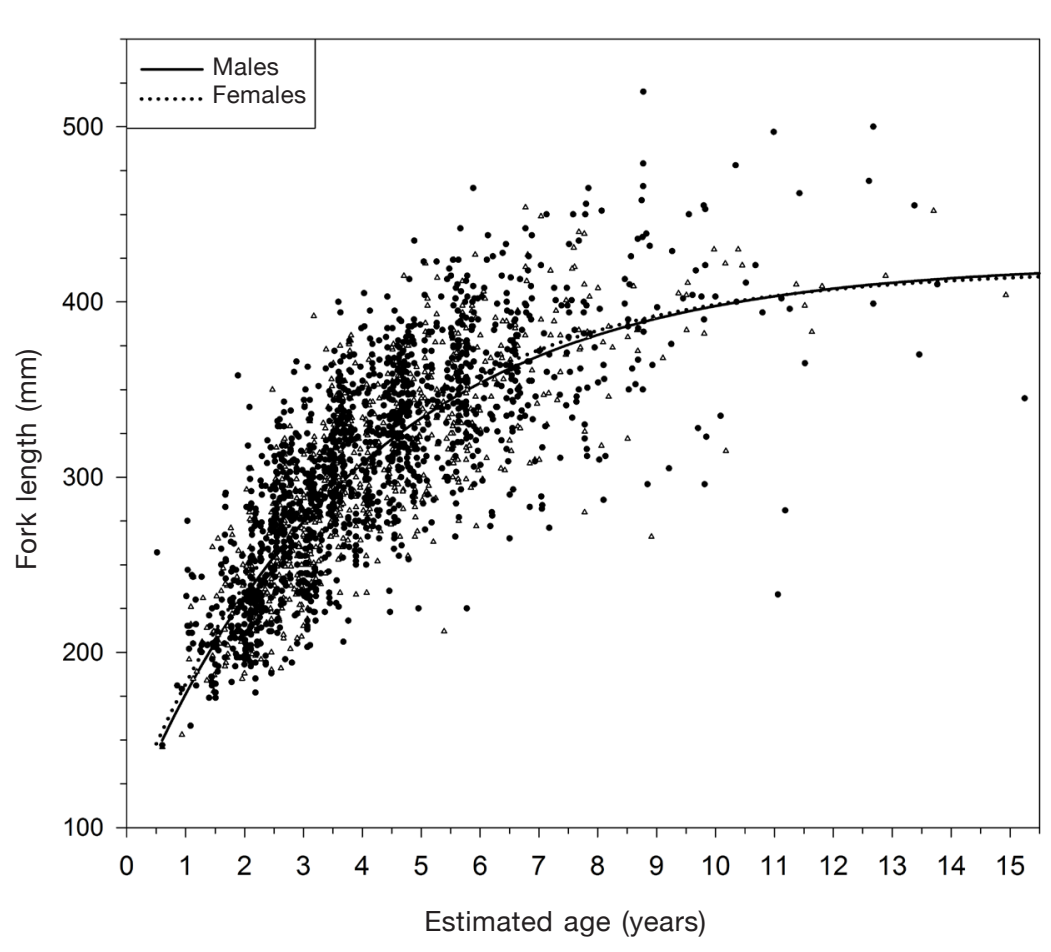

Figure 6

Observed fork lengths and estimated ages of female (indicated by black circles) and male (indicated by open triangles) sheepshead (Archosargus probatocephalus) collected in Tampa Bay, Florida, 1993-2009. The lines depict the predicted size at age from the von Bertalanffy growth models for males and females. Von Bertalanffy growth parameters for both sexes are presented in Table 3 .

\section{Growth}

Results of growth studies of sheepshead have shown marked geographic variation. Sheepshead in northern areas of the Gulf of Mexico and Atlantic are longer lived and grow larger than those in Florida (Beckman et al., 1991; Wenner ${ }^{3}$; DutkaGianelli and Murie, 2001). We found that the growth of sheepshead in Tampa Bay was similar to that reported farther north along the gulf coast of Florida. Sheepshead from Tampa Bay were observed to reach at least $524 \mathrm{~mm} \mathrm{FL}$ and to reach an estimated maximum age of 15 years. Dutka-Gianelli and Murie (2001) collected sheepshead in northwest Florida with a similar maximum age (15 years) and size (522 $\mathrm{mm}$ FL). In contrast, sheepshead from Louisiana (Beckman et al., 1991) lived longer (20 years) and grew larger $(563 \mathrm{~mm}$ FL) than sheepshead collected in Florida (Dutka-Gianelli and Murie, 2001; our study). Specimens collected in South Carolina (Wenner ${ }^{3}$ ) included the greatest reported estimated age for sheepshead (26 years). Wenner $^{3}$ also reported a sheepshead maximum size (560 $\mathrm{mm}$ FL) similar to that reported for sheepshead from Louisiana.

Fish length is a poor measure for estimating age in sheepshead. Sheepshead of similar age can differ considerably in length (Schwartz, 1990; Beckman et al., 1991; Wenner ${ }^{3}$; Dutka-Gianelli and Murie, 2001; our study). For example, in our study, age-5 sheephead ranged from 212 to $465 \mathrm{~mm} \mathrm{FL}$, and 350-mm-FL specimens ranged from age 2 to age 8 . Length has also been seen as unreliable for estimating the age for other sparids, including red porgy (Pagrus pagrus; Hood and Johnson, 2000), black bream (Acanthopagrus butcheri; Sarre and Potter, 2000), pinfish (Lagodon rhomboides; Nelson, 2002), and littlehead porgy (Calamus proridens; Tyler-Jedlund and Torres, 2015).

Although growth models for male and female sheepshead from Tampa Bay differed statistically, the actual growth parameters were biologically very similar for the sexes. Sex-specific growth models had a significantly 


\section{Table 3}

Estimates of the von Bertalanffy growth parameters, by sex, and with sexes combined: asymptotic length $\left(L_{\infty}\right)$, growth coefficient $(k)$, and hypothetical age at size zero $\left(t_{0}\right)$ for sheepshead (Archosargus probatocephalus) collected in Tampa Bay, Florida, 1993-2009. Sample sizes ( $n$ ) and asymptotic standard errors (in parentheses) are listed. Combined includes female and male sheepshead, as well as sheepshead for which sex was not determined $(n=169)$.

\begin{tabular}{|c|c|c|c|}
\hline & Females & Males & Combined \\
\hline$L_{\infty}(\mathrm{mm})$ & $419.1 \quad(7.206)$ & $422.5 \quad(9.948)$ & $418.7 \quad(5.309)$ \\
\hline$K$ & $0.272 \quad(0.019)$ & $0.255 \quad(0.023)$ & $0.273 \quad(0.014)$ \\
\hline$t_{0}$ & $-1.099 \quad(0.162)$ & $-1.115 \quad(0.205)$ & $-0.981 \quad(0.107)$ \\
\hline$n$ & 1429 & 797 & 2395 \\
\hline
\end{tabular}

5 and age 6 , respectively. The differences in growth parameters between these latter 2 studies may be attributed to differences in sampling methods, ontogenetic habitat shifts, or estuarine-specific differences in growth or mortality. Furthermore, the variation in growth parameters between these studies may also be affected by variability in genetic composition (subspecies) among the regions where these studies were conducted.

Reliance on fishery-dependent samples can introduce size- and agerelated biases that can result in misleading interpretations of fish growth and size distribution, and age structure of a population (Langler, 1978; Miranda et al., 1987; Hilborn and Wal-

better fit for sheepshead from Louisiana waters than a model in which sexes were combined. Predicted sizes at age for Louisiana sheepshead were similar for both sexes through age 6 , with a mean difference in size at age of $11.6 \mathrm{~mm}$ FL between the sexes (Table 4 ), but this difference in size was greater at older ages (25.8 $\mathrm{mm}$ difference in FL for ages 7-20). Despite finding no significant difference in sex-specific growth for sheepshead from northwest Florida, both sex-specific and combined-sex growth models were presented by Dutka-Gianelli and Murie (2001); mean differences in predicted size at age between sexes (11.2 mm FL) were larger than the differences we found (mean differences of only $3.3 \mathrm{~mm} \mathrm{FL}$; Table 4). Therefore, evidence of growth differences between males and females has often been varied among previous studies. For recent stock assessments of sheepshead in Florida, growth was assumed to be similar for males and females, but coast-specific growth parameters were used because growth varied significantly between the two regions (Munyandorero et al. ${ }^{1}$ ).

Our estimates of $L_{\infty}$ and the $t_{0}$ (Table 3 ) were within 2 standard errors of those estimated for fish from Louisiana waters (males: $L_{\infty}=419, t_{0}=-0.901$; females: $L_{\infty}=447, t_{0}=-1.025$; Beckman et al., 1991; Table 4). Estimated $L_{\infty}$ for sheepshead from South Carolina (505.0 $\mathrm{mm} \mathrm{FL}$ ) and northwest Florida (490.4 mm FL) were greater than those for sheepshead from either Tampa Bay or Louisiana. For sheepshead from South Carolina and northwest Florida and in our study, values of $k$ were similar but smaller than those reported for sheepshead in Louisiana, indicating that Louisiana sheepshead reach $L_{\infty}$ more rapidly. Beckman et al. (1991) found predicted lengths for age-3 Louisiana male and female sheepshead were $80 \%$ and $77 \%$ of their $L_{\infty}$, respectively. We found that sheepshead in Tampa Bay are not predicted to reach $80 \%$ of $L_{\infty}$ until age 5 for females (81\%) and age 6 for males (83.8\%). Similarly, in studies conducted in South Carolina (Wenner ${ }^{3}$ ) and northwest Florida (Dutka-Gianelli and Murie, 2001), sheepshead were predicted to reach $80 \%$ of $L_{\infty}$ by age ters, 1992). All the sheepshead analyzed in a Louisiana study were collected from commercial and recreational catches. Almost $60 \%$ of their fish came from catches with gill nets, which tend to be size selective, often resulting in a narrow size range of collected fish (Pope et al., 1975). Beckman et al. (1991) indicated that their sample of sheepshead was probably not representative of the Louisiana population because of gear selectivity and sorting of catches before sampling. In a South Carolina study, most sheepshead larger than $300 \mathrm{~mm}$ FL were caught in recreational fishing tournaments and probably represented a greater percentage of larger fish than that of the overall population (Wenner ${ }^{3}$ ). Consequently, the sampling methods of these studies could have introduced sufficient size-at-age bias to the effect that the sampled fish did not represent the population as a whole. Our fisheries-independent sampling design increased the likelihood that our data would approximately represent the size and age structure of the population of sheepshead in Tampa Bay. Specimens were collected by using a variety of gear types (a majority of specimens with the nonselective large haul seine $[77 \%]$ ), and at randomly selected sites $(68 \%)$ that represented a variety of habitats.

Adult sheepshead have been reported to occur over hard structure (reefs, jetties, and piers) in both estuarine (Johnson, 1978; Ogburn, 1984) and offshore (Sedberry and van Dolah, 1984) waters. Sheepshead also have been reported to undergo an ontogenetic shift in habitat as juveniles (Hildebrand and Cable, 1938; Johnson, 1978), moving from shallow nursery habitats, which often include sea grasses, to hard-structure habitats of adults. Sheepshead in our study were collected from relatively shallow waters (mean depth: 1.2 $\mathrm{m}$ [standard error 0.02]) in the Tampa Bay estuary, whereas portions of sheepshead in the Louisiana and northwest Florida studies came from deeper, offshore areas. Render and Wilson (1992) found no significant differences in size or age between the sheepshead collected in offshore and inshore waters of Louisiana, but sample size and gear selectivity (i.e., similar among 


\section{Table 4}

Estimates of the von Bertalanffy growth parameters, the asymptotic length $\left(L_{\infty}\right)$, growth coefficient $(k)$, and hypothetical age at size zero $\left(t_{0}\right)$, and the predicted size at age, presented in fork length (FL) in millimeters, for sheepshead (Archosargus probatocephalus) collected from in Tampa Bay, Florida, 1993-2009 (this study); Louisiana, 1987-1988 (Beckman et al., 1991); northwest Florida, 1997-1998 (Dutka-Gianelli and Murie, 2001); and South Carolina, 1995-1996 (Wenner³).

\begin{tabular}{|c|c|c|c|c|c|c|c|c|}
\hline \multirow[b]{2}{*}{ Growth parameters } & \multicolumn{2}{|c|}{ Tampa Bay } & \multicolumn{2}{|c|}{ Louisiana } & \multicolumn{3}{|c|}{ Northwest Florida } & \multirow{2}{*}{$\frac{\text { South Carolina }^{1,2}}{\text { Combined }}$} \\
\hline & Females & Males & Females & Males & Combined & Females & Males & \\
\hline$L_{\infty}(\mathrm{mm} \mathrm{FL})$ & 419.1 & 422.5 & 447.0 & 419.0 & 490.4 & 475.7 & 509.2 & 505.0 \\
\hline$k$ & 0.272 & 0.255 & 0.367 & 0.417 & 0.260 & 0.280 & 0.230 & 0.290 \\
\hline$t_{0}$ & -1.099 & -1.115 & -1.025 & -0.901 & -0.420 & -0.460 & -0.520 & -1.109 \\
\hline
\end{tabular}

Predicted size at ages ( $\mathrm{mm} \mathrm{FL)}$

\begin{tabular}{|c|c|c|c|c|c|c|c|c|}
\hline 0 & 109 & 105 & & & & & & 139 \\
\hline 1 & 183 & 177 & & & 151 & 160 & 150 & 231 \\
\hline 2 & 239 & 232 & 300 & 294 & 229 & 237 & 224 & 299 \\
\hline 3 & 282 & 275 & 345 & 337 & 289 & 295 & 283 & 351 \\
\hline 4 & 315 & 308 & 376 & 365 & 335 & 339 & 329 & 389 \\
\hline 5 & 340 & 334 & 398 & 383 & 371 & 373 & 366 & 418 \\
\hline 6 & 359 & 354 & 413 & 395 & 398 & 398 & 396 & 440 \\
\hline 7 & 373 & 370 & 423 & 403 & 419 & 417 & 419 & 456 \\
\hline 8 & 384 & 382 & 431 & 409 & 435 & 431 & 437 & 469 \\
\hline 9 & 393 & 391 & 436 & 412 & 448 & 442 & 452 & 478 \\
\hline 0 & 399 & 398 & 439 & 415 & 458 & 450 & 464 & 485 \\
\hline 11 & 404 & 404 & 442 & 416 & 465 & 456 & 473 & 490 \\
\hline 12 & 408 & 408 & 443 & 417 & 471 & 461 & 481 & 494 \\
\hline 13 & 411 & 411 & 444 & 418 & 475 & & 486 & 497 \\
\hline 14 & 413 & 414 & 445 & 418 & 479 & & 491 & 499 \\
\hline 15 & 414 & 416 & 446 & 418 & 482 & & 495 & 500 \\
\hline 16 & & & 446 & 419 & & & & 502 \\
\hline 17 & & & 446 & 419 & & & & 503 \\
\hline 18 & & & 447 & 419 & & & & 503 \\
\hline 19 & & & 447 & 419 & & & & 504 \\
\hline 20 & & & 447 & 419 & & & & 504 \\
\hline 1 & & & & & & & & 504 \\
\hline 22 & & & & & & & & 505 \\
\hline 23 & & & & & & & & 505 \\
\hline 24 & & & & & & & & 505 \\
\hline 25 & & & & & & & & 505 \\
\hline 6 & & & & & & & & 505 \\
\hline
\end{tabular}

areas) may have obscured differences. If sheepshead undergo a habitat shift from shallow nearshore waters into deeper waters, the growth parameters we describe might not indicate the age and growth of sheepshead in the deeper habitats.

Regional differences in sheepshead growth parameters may be attributed partly to population genetics. Within the U.S. range of this species, 2 subspecies of sheepshead have been reported (Caldwell, 1965). We analyzed $A$. p. probatocephalus, which occurs along the Atlantic coast and into the Gulf of Mexico to Steinhatchee, Florida. A Louisiana study (Beckman et al., 1991) considered A. p. oviceps, which occurs in the Gulf of Mexico from St. Marks River, Florida, to Campeche Bank, Mexico. A study from northwest Florida (DutkaGianelli and Murie, 2001) looked at both subspecies ( $84 \%$ A. a. probatocephalus and $11 \%$ A. a. oviceps) and found no significant differences in growth. Anderson et al. (2008) concluded that molecular genetic data indicated a very limited genetic subdivision between the subspecies, despite considerable divergence in some morphological characters.

In contrast, recent analyses of 24 species-specific microsatellite DNA loci of both $A$. probatocephalus subspecies from the Atlantic (Florida to North Carolina) and the Gulf of Mexico (Florida and Texas), showed a 
genetic break at the site of the subspecies boundary at Apalachee Bay, Florida (Seyoum et al., in press). These recent genetics results, coupled with the known morphological differences between A. p. probatocaphalus and $A$. $p$. oviceps, support the validity of the 2 subspecies of sheepshead within its U.S. range (Caldwell, 1965), but further study is necessary to better understand processes that contribute to the genetic and morphological differences between these subspecies. A comparison of similarly collected age and growth data is necessary to determine the existence and extent of any subspecific differences in growth.

A fishery can modify the population size and age characteristics of a species by selectively removing younger, faster-growing fish (Ricker, 1975), possibly accounting for the larger fish collected in northwest Florida. Dutka-Gianelli and Murie (2001) suggested that because of the lower density of the human population of northwest Florida, sheepshead there may have experienced less long-term fishing mortality than those in Tampa Bay. Sheepshead enter the fishery in Florida waters at $\sim 280 \mathrm{~mm}$ FL $(\sim 305 \mathrm{~mm}$ TL$)$, at approximately the size predicted for age-3 sheepshead in Tampa Bay (Table 4). Predicted sizes at age are similar between sheepshead in Tampa Bay and those in northwest Florida through age 3 (mean difference of 13.2 $\mathrm{mm}$ FL), but after that age, sheepshead from northwest Florida consistently are predicted to attain larger sizes at age (mean difference of $52.4 \mathrm{~mm} \mathrm{FL}$ ).

Regional differences in sheepshead growth parameters are apparent, but within Florida waters it is unnecessary to manage sheepshead regionally. Several fishery management actions, including the ban on entangling gear, a minimum size limit, and recreationalbag (15 fish) and commercial-possession (50 fish) limits were enacted for sheepshead in Florida waters during the 1990s. These actions have brought about a decrease in combined landings of sheepshead and an increase in the size of sheepshead landed; transitional spawning potential ratios of sheepshead in Florida have increased since 1996 and, in 2009, were 37\% and 29\% for the Atlantic and gulf coasts of Florida, respectively (Munyandorero et al. ${ }^{1}$ ). Further studies, to better define the stock structure and to describe estuary- or stock-specific differences in growth, would be beneficial and help refine the management of sheepshead in Florida waters.

\section{Acknowledgments}

We thank staff of the Florida Fish and Wildlife Conservation Commission's Fisheries-Independent Monitoring program and its Age and Growth Lab for aiding with sample collection and processing and the preparation and reading of otoliths, D. Harshany for measuring marginal increments, and R. Crabtree and M. Murphy for scientific expertise. We also are grateful to D. Leffler, T. Tsou, A. Acosta, R. Taylor, M. Murphy, R. McMichael, J. Quinn, J. Leiby, and B. Crowder for their critical reviews that greatly improved this manuscript. This work was supported in part by funding from the U.S. Fish and Wildlife Service under Federal Aid for Sportfish Restoration Project Number F-43 as well as from Florida's saltwater fishing licenses. The statements, findings, views, conclusions, and recommendations contained in this document are those of the authors and do not necessarily reflect the views of the U.S. Department of the Interior and should not be interpreted as representing the opinions or policies of the U.S. government.

\section{Literature cited}

Anderson, J. D., W. J. Karel, K. A. Anderson, and P. A. RoperFoo.

2008. Genetic assessment of sheepshead stock structure in the northern Gulf of Mexico: morphological divergence in the face of gene flow. North Am. J. Fish. Manage. 28:592-606. Article

Bagenal, T. B., and F. W. Tesch.

1978. Age and growth. In IBP handbook no. 3: methods for assessment of fish production in freshwater, $3^{\text {rd }}$ ed. (T. B. Bagenal, ed.), p. 101-136. Blackwell Scientific Publications, Oxford, UK.

Beamish, R. J., and G. A. McFarlane.

1983. The forgotten requirement for age validation in fisheries biology. Trans. Am. Fish. Soc. 112:735-743. Article

Beckman, D. W., A. L. Stanley, J. H. Render, and C. A. Wilson.

1991. Age and growth-rate estimation of sheepshead Archosargus probatocephalus in Louisiana waters using otoliths. Fish. Bull. 89:1-8.

Bigelow, H. B., and W. C. Schroeder.

1953. Fishes of the Gulf of Maine. Fish. Bull. 53:1-577.

Caldwell, D. K.

1965. Systematics and variation in the sparid fish Archosargus probatocephalus. Bull. South. Calif. Acad. Sci. 64:89-100.

Carlander, K. D.

1987. A history of scale age and growth studies of North American freshwater fish. In Age and growth of fish ( $\mathrm{R}$. C. Summerfelt and G. E. Hall, eds.), p. 3-14. Iowa State Univ. Press, Ames, IA.

Collette, B. B., and G. Klein-MacPhee (eds.).

2002. Bigelow and Schroeder's fishes of the Gulf of Maine, $3^{\text {rd }}$ ed., 748 p. Smithsonian Inst. Press, Washington, D.C.

Comp, G. S., and W. Seaman Jr.

1985. Estuarine habitat and fishery resources of Florida. In Florida aquatic habitat and fishery resources (W. Seaman Jr., ed.), p. 337-435. Fla. Chapter Am. Fish. Soc., Eustis, FL.

Dutka-Gianelli, J.

1999. Comparative age and growth of sheepshead, Archosargus probatocephalus (Walbaum 1972) (Pisces: Sparidae), from the northwestern coast of Florida. M.S. thesis, 68 p. Univ. Florida, Gainesville, FL.

Dutka-Gianelli, J., and D. J. Murie.

2001. Age and growth of sheepshead, Archosargus probatocephalus (Pisces: Sparidae), from the northwest coast of Florida. Bull. Mar. Sci. 68:69-83.

Gilhen, J., C., G. Grunchy, and D. E. McAllister. 1976. The sheepshead, Archosargus probatocephalus, and 
the feather blenny, Hypsoblennius hentzi, two additions to the Canadian Atlantic ichthyofauna. Can. Field-Nat. 90:42-46.

Helser, T. E.

1996. Growth of silver hake within the U.S. continental shelf ecosystem of the northwest Atlantic Ocean. J. Fish Biol. 48:1059-1073. Article

Hilborn, R., and C. J. Walters.

1992. Quantitative fisheries stock assessment: choice, dynamics and uncertainty, 570 p. Routledge, Chapman and Hall Inc., New York.

Hildebrand, S. F., and L. E. Cable.

1938. Further notes on the development and life history of some teleosts at Beaufort, N.C. Bull. Bur. Fish. 48:505-642.

Hood, P. B., and A. K. Johnson.

2000. Age, growth, mortality, and reproduction of red porgy, Pagrus pagrus, from the eastern Gulf of Mexico. Fish. Bull. 98:723-735.

Johnson, D. G.

1978. Development of fishes in the mid-Atlantic Bight IV: Carangidae through Ephippidae. U.S. Fish Wildl. Serv., FWS/OBS-78/12, 314 p.

Lowerre-Barbieri, S. K., M. E. Chittenden Jr., and C. M. Jones. 1994. A comparison of a validated otolith method to age weakfish, Cynoscion regalis, with the traditional scale method. Fish. Bull. 92:555-568.

Miranda, L. E., W. M. Wingo, R. J. Muncy, and T. D. Bates.

1987. Bias in growth estimates derived from fish collected by anglers. In Age and growth of fish (R. C. Summerfelt and G. E. Hall, eds.), p. 211-220. Iowa State Univ. Press, Ames, IA.

Nelson, G. A.

1998. Abundance, growth, and mortality of young-of-the year pinfish, Lagodon rhomboides, in three estuaries along the gulf coast of Florida. Fish. Bull. 96:315-328.

2002. Age, growth, mortality, and distribution of pinfish (Lagodon rhomboides) in Tampa Bay and adjacent Gulf of Mexico waters. Fish. Bull. 100:582-592.

Nelson, G. A., R. H. McMichael, T. C. MacDonald, and J. R. O'Hop.

1997. Fisheries monitoring and its uses in fisheries resources management. In Proceedings, Tampa Bay area scientific information symposium 3: applying our knowledge; Clearwater, FL; 21-23 October 1996 (S. F. Treat, ed.), p. 43-56. Tampa Bay Regional Planning Council, Clearwater, FL.

Ogburn, M. V.

1984. Feeding ecology and the role of algae in the diet of sheepshead Archosargus probatocephalus (Pisces: Sparidae) on two North Carolina jetties. M.S. thesis, 68 p. Univ. North Carolina, Wilmington, NC.

Parsons, G. R., and K. M. Peters.

1989. Age determination in larval and juvenile sheepshead, Archosargus probatocephalus. Fish. Bull. 87:985988.

Pope, J. A., A. R. Margetts, J. M. Hamley, and E. F. Akyuz.

1975. Manual of methods for fish stock assessments. Part III. Selectivity of fishing gear. FAO Fish. Tech. Pap. 41, $65 \mathrm{p}$.
Render, J. H., and C. A. Wilson.

1992. Reproductive biology of sheepshead in the northern Gulf of Mexico. Trans. Am. Fish. Soc. 121:757764. Article

Ricker, W. E.

1975. Computation and interpretation of biological statistics of fish populations. Bull. Fish. Res. Board Can. 191, $382 \mathrm{p}$.

Sarre, G. A., and I. C. Potter.

2000. Variation in age compositions and growth rates of Acanthopagrus butcheri (Sparidae) among estuaries: some possible contributing factors. Fish Bull. 98:785799.

Schwartz, F. J.

1990. Length-weight, age and growth, and landings observations for sheepshead Archosargus probatocephalus from North Carolina. Fish. Bull. 88:829-832.

Sedberry, G. R., and R. F. van Dolah.

1984. Demersal fish assemblages associated with hard bottom habitat in the South Atlantic Bight of the U.S.A. Environ. Biol. Fish. 11:241-258. Article

Seyoum, S., R. S. McBride, C. Puchutulegui, J. Dutka-Gianelli, A. C. Alavarez, and K. Panzner.

In press. Genetic population structure of a coastal marine fish (Sheepshead; Archosargus probatocephalus [Sparidae]) in the southeastern United States: multiple population clusters based on species-specific microsatellite markers. J. Mar. Sci.

Snedecor, G. W., and W. G. Cochran.

1967. Statistical methods, 593 p. Iowa State Univ. Press, Ames, IA.

Sokal, R. R., and F. J. Rohlf.

1981. Biometry: the principles and practice of statistics in biological research, $2^{\text {nd }}$ ed., 859 p. W.H. Freeman and Company, New York.

Tremain, D. M., and D. H. Adams.

1995. Seasonal variations in species diversity, abundance, and composition of fish communities in the northern Indian River Lagoon, Florida. Bull. Mar. Sci. 57:171-192.

Tucker, J. W., Jr., and S. R. Alshuth.

1997. Development of laboratory-reared sheepshead, Archosargus probatocephalus (Pisces: Sparidae). Fish. Bull. 95:394-401.

Tyler-Jedlund, A. J., and J. J. Torres.

2015. Age, growth, and reproduction of the littlehead porgy, Calamus proridens, from the eastern Gulf of Mexico. Bull. Mar. Sci. 91:101-123. Article

von Bertalanffy, L.

1957. Quantitative laws in metabolism and growth. Q. Rev. Biol. 32:217-231. Article

Wilson, K. L., B. G. Matthias, A. B. Barbour, R. N. M. Ahrens, T. Tuten, and M. S. Allen.

2015. Combining samples from multiple gears helps to avoid fishy growth curves. North Am. J. Fish. Manage. 35:1121-1131. Article

Winner, B. L., D. A. Blewett, R. H. McMichael Jr., and C. B. Guenther.

2010. Relative abundance and distribution of common snook along shoreline habitats of Florida estuaries. Trans. Am. Fish. Soc. 139:62-79. Article 